\title{
ЗАПОЗИЧЕННЯ В ТЕРМІНОЛОГІЇ НАНОТЕХНОЛОГІЙ
}

У статті проаналізовано чужомовні спеціальні назви, що застосовуються у сфері нанотехнологій. 3'ясовано, що досліджувана термінологія має міжнародний характер, тому містить значну кількість одиниць, утворених iз залученням греко-латинських терміноелементів, і терміни, запозичені з англійської мови. Установлено шляхи запозичення термінів нанотехнологій, способи їх пристосування до системи української літературної мови. Виокремлено структурні типи запозичених термінів, а також одиниць, що містять запозичені та питомі компоненти, поєднання яких є результатом транслітерації, адаптації, гібридизації й калькування чужомовних термінів.

Ключові слова: термінологія нанотехнологій, запозичений термін, запозичений компонент, питомий компонент, гібридотермін.

Krymets O. Linguistic Borrowing in Nanotechnology Terminology. The article is devoted to the study of borrowed special names of nanotechnology terminology. The purpose of the article is to study the foreign terms in the sphere of nanotechnology, namely: means of borrowing, methods of their application in the system of Ukrainian language, types of borrowed terms, as well as some units with borrowed components, which have never been the object of a special analysis in the science of terminology and are of great interest to study.

The studied terminology is international, that is why there are many units created by means of Greek and Latin terminological elements, which are joined with borrowed and significant Ukrainian lexical units. Greek and Latin morphemes, which are the basis of international components, meet requirements of the accuracy, shortness and unambiguity of a term. The "nano" component is the most common one in the terminology of nanotechnology. In the analysed terminology the terms of English derivation have also been found.

It has been established, that in the nanotechnology terminology there are some units, borrowed by means of transliteration, as well as the terms that have obtained significant suffixes, that is, have attached to the norms of the target language. Hybrid terms represent a large group; they are created as a consequence of a combination of national and derived components, which is the result of borrowing of foreign units by different ways - transliteration, adoption, hybridization and calking.

The structural analysis of the terms has shown that not only one-component term combinations are widespread, but two-, three- and multicomponent terms-word combinations, containing such significant components, are widespread as well. Borrowed terms are adopted to the norms of the Ukrainian standard language by means of suffixes and subordination of the case system. 
Thus, it can be concluded, that borrowing of foreign units is an active way of developing the nanotechnology terminology.

Key words: nanotechnology terminology, borrowed term, borrowed component, significant component, hybrid term.

\section{Вступ}

Над проблемами нанотехнологій працюють наукові колективи всього світу, через це її термінологія має міжнародний характер, тобто містить значну кількість одиниць, утворених із залученням греко-латинських терміноелементів, а також терміни, запозичені з англійської мови.

Запозичення як однин зі способів поповнення новими одиницями складу різних терміносистем є предметом досліджень багатьох наукових студій: фінансово-кредитна термінологія (Козловець, 2003), технічна (Козак, 2007), термінологія менеджменту (Краснопольська, 2010), фізична (Процик, 2003), правнича термінологія (Сергєєва, 2002), термінологія швацької промисловості (Романова, 2012), комп’ютерна термінологія (Ментинська, 2014) та ін. Однак у сучасній лінгвістиці немає наукових праць, присвячених дослідженню запозичень у термінології нанотехнологій, тому метою статті є вивчення таких спеціальних одиниць сфери нанотехнологій, а саме: 1) шляхів запозичення термінів, 2) способів їх пристосування до системи української мови, 3) типів запозичених термінів, а також 4) одиниць із запозиченими компонентами, що не було об’єктом спеціального аналізу в термінознавстві й становить актуальність пропонованої наукової роботи.

\section{Методи дослідження}

Для вивчення кожної термінологічної одиниці в структурному та семантичному аспектах застосовано аналітико-описовий метод, а також методи дефінітивного аналізу для дослідження плану змісту термінів та уточнення їх приналежності до термінології нанотехнологій. Залучено також методи номінативного, елементи когнітивного аналізу для узагальнення і класифікації спеціальних одиниць.

\section{Виклад основного матеріалу}

Аналіз лексикографічних джерел свідчить, що найбільшу кількість запозичень в українській термінології нанотехнологій становлять одиниці з латинської, давньогрецької та англійської мов. I. Кочан стверджує, що греко-латинські морфеми, покладені в основу 
міжнародних компонентів, відповідають вимогам точності, короткості й однозначності терміна (Кочан, 2013). У терміносистемі нанотехнологій такі компоненти поєднуються із запозиченими та питомими українськими лексемами. Найпоширеніший компонент “нано”, що має давньогрецьке походження й перекладається як “карлик”, є складовим компонентом таких термінів, як нанотрубка, наномасштабний, нанопорошок, нанодатчик, нановолокна та багатьох інших. Продуктивними також $€$ й інші греко-латинські терміноелементи: “піро” (niролітичний), “електро” (електромагнітний), “мікро” (мікроробот), “анод” (анодування), “анти” (антигенік), “біо” (біологічний), “гетеро” (гетероепітаксія), “макро” (макропори), “мезо” (мезопористий), “ультра” (ультрадисперсний), “фото” (ботоелектронний), “інфра” (інбрачервоний), “гідро” (гідравлічний), “граф” (літограбія), “кристал” (кристалізація). В аналізованій термінології виявлено також терміни англійського походження: актюратор, асемблер, кантилевер, лазер, дендример та інші.

Запозичені терміни пристосовуються до норм української літературної мови. На думку І. Кочан, запозичені слова можна поділити на дві групи: ті, які увійшли в нашу мову без особливих змін (лише в українській транслітерації): анод, катод, адаптація, конфігурація, монтаж, стаж, репортаж тощо, і такі, що пристосувалися в нашій мові, отримали національну афіксацію або вже не сприймаються як запозичені: вібрування, школа, селективність (Кочан, 2008). Подібні процеси спостерігаємо й у термінології нанотехнологій, де наявні терміни, запозичені шляхом транслітерації (алмазоїд, дизасемблер, мікрон), а також одиниці, що отримали питомі суфікси, тобто певним чином пристосувалися до норм мови-реципієнта (трансмісійниц̆, мікрорідинний, кріохімічний, нанодрукарський, анодування, ультрадисперсний). Велику групу становлять гібридотерміни, які утворилися в результаті поєднання національного та запозиченого коренів: нановолокна, мікрозахоплювач, іонно-променевий.

Серед запозичених одиниць досліджуваної термінології за структурою виокремлюємо однокомпонентні, складні та терміни-словосполучення. Компоненти складних термінів та термінів-словосполучень можуть бути як запозиченими, так і питомими.

Запозичені однокомпонентні терміни нанотехнологій представлені одиницями трьох типів. До першого типу належать такі, 
що складаються з одного кореня (мікрон, канал). Другий тип термінів - це спеціальні назви, що містять у своєму складі іншомовні суфікси (актюратор, алмазоїд, асемблер, дендример), третій тип - терміни, що в результаті пристосування до норм української мови отримали питомі суфікси (амбіфільний, анодування, дисперсність).

Складні терміни нанотехнологій становлять два типи:

1) одиниці, де всі компоненти $є$ іншомовними: антигенік, біонанотехнологія, біопотенціал, біоіненерія, гетероепітаксія, гетероструктура, еліпсометр, макропори, мезопори, мікроклапан, мікропори, мікрореле, мікропінцет, мікроскоп, мікрофагоиит, наноалмаз, нанобіотехнологія, нановіскер, прини-технологія, ультрацентрифуга, фотополімеризація;

2) гібридотерміни, у яких запозичений компонент греко-латинського походження поєднується з питомим: нанонаповнювач, нанонаука, нанопорошок, нанорідини, нанострижень, нанострічка, нанотрубка, наночастка, наночорнила, наношар, нанодріт, нанодатчик, нановолокна, антитіла, дельта-легування, електронно-променевий, інфрачервоний, іонно-променевий, нановаги, мікрозахоплювач, мікрокування, мікронасос, мікроотвір, мікроперемикач, мікротвердість, субиорсткість.

Серед термінів-словосполучень виділяємо такі типи:

1. Двокомпонентні:

- питомий компонент + запозичений компонент: вбивчий дефект, волокна борні;

- запозичений компонент + запозичений компонент: інериійний сенсор, інтегральна оптика, інтегральна схема, каучуковий актюратор, колоїдна система;

- запозичений компонент + питомий компонент: дисперсна частинка, інтенсивність шуму, квантова точка, квантова яма, квантовий дріт, квантовий загін, колоїдний розчин, магнітна рідина, молекулярні сита, хімічний підшипник.

2. Двокомпонентні, один із компонентів яких є складним:

- запозичений компонент + гібридотермін: компактування нанопорочків, інтегральний тензодатчик, хіральність нанотрубки;

- запозичений компонент + запозичений (складний) компонент: матеріал наноструктурований, медичний наноробот, мембрана біологічна, продукція наноіндустрії, синтез кріохімічниц, фулеренова наноструктура; 
- запозичений (складний) компонент + питомий компонент: наноматеріали вуглецеві, дезоксирибонуклеїнова кислота;

- запозичений (складний) компонент + запозичений компонент: електромагнітний актюратор, електростатичний актюратор, мезопористий матеріал, ультрадисперсна частинка, літограбія рентгенівська;

- питомий компонент + запозичений (складний) компонент: cniкання нанокераміки;

- питомий компонент + гібридотермін: частка нанопорошку;

- гібридотермін + питомий компонент: нанотрубка вуглещева, мікрообробка об'ємна;

- гібридотермін + запозичений термін: молекулярно-променева епітаксія;

- гібридотермін + запозичений (складний) компонент: атомносиловици мікроскоп.

3. Двокомпонентні, у яких обидва компоненти складні:

- запозичений компонент + гібридотермін: літограбія іонно-променева;

- запозичений компонент + запозичений компонент: іонно-трекова технологія, літографія наносферами, літографія ультрафіолетова, літографія нанодрукарська, морфологія наноструктур;

- гібридотермін + гібридотермін: мезорівнева мікрообробка;

- гібридотермін + запозичений компонент: атомно-силова мікроскопія.

4. Трикомпонентні терміни:

- запозичений компонент + запозичений компонент + питомий компонент: кристалізація аморфних сплавів;

- запозичений компонент + запозичений компонент + запозичений компонент: інструмент зондового сканування, інтенсивна пластична дебормачія;

- питомий компонент + запозичений компонент + питомий компонент: иибулинна форма вуглецю.

5. Трикомпонентні терміни, що містять складні компоненти:

- запозичений компонент + запозичений компонент + гібридотермін: хіральна структура нанотрубки;

- запозичений компонент + питомий компонент + запозичений (складний): вектори на основі наноматеріалів; 
- запозичений компонент + гібридотермін + запозичений (складний) компонент: синтез нанопорошків плазмохімічний;

- запозичений (складний) + запозичений компонент + запозичений (складний): спектроскопія рентгенівська фотоелектронна, мікроскоп електронний трансмісійний;

- запозичений (складний) + питомий компонент + гібридотермін: піролітичне отримання нанопорошків;

- запозичений (складний) + питомий компонент + питомий компонент: мікроробот для дослідження труб;

- питомий компонент + запозичений компонент + гібридотермін: помел механічний високоенергетичний;

- питомий (складний) компонент + запозичений компонент + питомий компонент: малокутове нейтронне розсіювання, малокутове рентгенівське розсіювання;

- гібридотермін + запозичений компонент + запозичений компонент: мікрообробка ексимерним лазером, мікрорідинна молекулярна система;

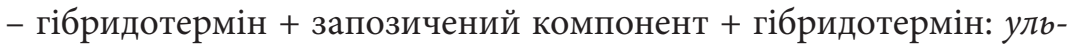
тразвукове пресування нанопорошків.

6. Чотири- та п’ятикомпонентні терміни:

- усі компоненти запозичені: інтегральна система хімічного аналізу, масспектрометрія лазерною десорбиією й іонізацією;

- запозичені та питомі компоненти: інтегральний контролер масової витрати, мікроскопія фолуоресцентна повного внутрішнього віддзеркалення, тертя на мікро- та наномасштабному рівні.

Таке складне поєднання запозичених і питомих компонентів у структурі термінів нанотехнологій $є$ результатом запозиченням чужомовних одиниць неоднаковим шляхом - транслітерації, адаптації, гібридизації та калькування.

\section{Висновки}

Отже, активним шляхом розбудови термінології нанотехнологій є запозичення чужомовних одиниць. Структурний аналіз цих термінів свідчить, що, окрім однокомпонентних, досить поширені складні та терміни-словосполучення, які утворилися внаслідок поєднання як іншомовних, так і питомих компонентів. Джерелами запозичень слугують давньогрецька, латинська та англійська мови, 
що пояснюється міжнародним характером досліджуваної термінології. Запозичені терміни пристосовуються до норм української літературної мови шляхом суфіксації та підпорядкування системі відмінювання. Хоча розглянутий матеріал демонструє, що чужомовні терміни переважають за своєю кількістю, наявні й питомі компоненти, які є результатом калькування.

Перспективним уважаємо подальше вивчення питань теоретичного й практичного характеру у сфері термінологічних запозичень для розв'язання проблеми мовного унормування спеціальних назв, що поповнюють термінологію нанотехнологій української мови.

\section{ЛІТЕРАТУРА}

1. Козак, Л. (2007). Запозичення як складова частина української технічної термінології. Украӥнська термінологія і сучасність, VII, 63-65. 2. Козловець, I. (2003). Роль запозичень у формуванні української фінансово-кредитної термінології. Лінгвістичні студіi, 11 (2), 467-469. 3. Комарова, Л., \& Залєський, Є. (2011). Нанотехнологіі. Украйнсько-російський словник-довідник кониептуальних понять. Київ: ВІКНУ. 4. Кочан, I. (2008). Термінологія: національна чи міжнародна? Термінологія, 620, 3-8. 5. Кочан, I. (2013). Украӥнська наукова лексика: міжнародні компоненти в термінолоzіï. Київ: Знання. 6. Краснопольська, Н. (2010). Запозичення в українській термінології менеджменту. Проблеми української термінологіï, 675, 125-130. 7. Ментинська, I. (2014). Лексико-генетичні особливості сучасної комп'ютерної термінології. Проблеми украйнської термінологіï, 791, 71-74. 8. Процик, I. (2003). Запозичення та освоєння чужомовної лексики в українській фізичній термінології на зламі XIX-XX століть. Украйнська термінологія і сучасність, V, 167-169. 9. Романова, О. (2012). Запозичення в українській термінології швацької промисловості. Мовознавчий вісник, 14-15, 75-83. 10. Сергєєва, Г. А. (2002). Англомовні запозичення в українській правничій термінології. (Автореф. дис. ... канд. філол. наук). Харків: ХНУ ім. В. Н. Каразіна.

\section{REFERENCES}

1. Kozak, L. (2007). Zapozychennia yak skladova chastyna ukrainskoi tekhnichnoi terminolohii [Borrowing as a constituent part of the Ukrainian technical terminology]. Ukrainska terminolohiia i suchasnist - Ukrainian terminology and modernity, VII, 63-65 [in Ukrainian]. 2. Kozlovets, I. (2003). Rol zapozychen u formuvanni ukrainskoi finansovokredytnoi terminolohii [The role of borrowed words in the formation of Ukrainian financial and credit terminology]. Linhvistychni studii - Linguistic studies, 11 (2), 467-469 [in Ukrainian]. 3. Komarova, L., \& Zalieskyi, Ye. (2011). Nanotekhnolohii. Ukrainskorosiiskyi slovnyk-dovidnyk kontseptualnykh poniat [Nanotechnologies. Ukrainian and Russian Dictionary of conceptual notions]. Kyiv: VIKNU [in Ukrainian]. 4. Kochan, I. (2008). Terminolohiia: natsionalna chy mizhnarodna? [Terminology: national or international?]. Terminolohiia - Terminology, 620, 3-8 [in Ukrainian]. 5. Kochan, I. (2013). Ukrainska naukova leksyka: mizhnarodni komponenty v terminolohii [Ukrainian scientific vocabulary: international components in terminology]. Kyiv: Znannia [in Ukrainian]. 6. Krasnopolska, N. 
(2010). Zapozychennia v ukrainskii terminolohii menedzhmentu [Borrowed words in Ukrainian terminology of management]. Problemy ukrainskoi terminolohii-Problems of Ukrainian terminology, 675, 125-130 [in Ukrainian]. 7. Mentynska, I. (2014). Leksyko-henetychni osoblyvosti suchasnoi kompiuternoi terminolohii [Lexical and genetic features of modern computer terminology]. Problemy ukrainskoi terminolohii - Problems of Ukrainian terminology, 791, 71-74 [in Ukrainian]. 8. Protsyk, I. (2003). Zapozychennia ta osvoiennia chuzhomovnoi leksyky v ukrainskii fizychnii terminolohii na zlami XIX-XX stolit [Borrowing and development of vocabulary in Ukrainian terminology of Physics at the turn of the $\mathrm{XIX}^{\text {th }}-\mathrm{XX}^{\text {th }}$ centuries]. Ukrainska terminolohiia $i$ suchasnist - Ukrainian terminology and modernity, V, 167-169 [in Ukrainian]. 9. Romanova, O. (2012). Zapozychennia v ukrainskii terminolohii shvatskoi promyslovosti [Borrowed words in Ukrainian terminology of tailoring industry]. Movoznavchyi visnyk - Linguistic Bulletin, 14-15, 75-83 [in Ukrainian]. 10. Serhieieva, H. A. (2002). Anhlomovni zapozychennia v ukrainskii pravnychii terminolohii [English borrowed words in Ukrainian Law terminology]. Extended abstract of candidate's thesis. Kharkiv: KhNU im. V. N. Karazina [in Ukrainian].

Кримець Оксана Михайлівна - кандидат філологічних наук, доцент, доцент кафедри української мови, Національний технічний університет «Харківський політехнічний інститут»; вул. Кирпичова, 2, м. Харків, 61000, Україна.

Tel.: +38-050-186-12-03

E-mail: oksana.krim@ukr.net

https://orcid.org/0000-0002-8401-3540

Krymets Oksana Mykhailivna - Candidate of Philological Sciences (Ph.D.), Docent, Associate Professor at the Department of Ukrainian Languages, National Technical University «Kharkiv Polytechnic Institute»; 2 Kyrpychova Str., Kharkiv, 61000, Ukraine.

Надійшла до редакції 5 вересня 2021 року

\section{CITATION}

ДСТУ 8302:2015: Кримець О. М. Запозичення в термінології нанотехнологій. Лінгвістичні дослідження: зб. наук. пр. Харк. нац. пед. ун-ту імені Г. С. Сковороди. Харків, 2021. Вип. 55. С. 68-75. DOI: https://doi.org/10.34142/23127546.2021.55.07

APA: Кримець, О. М. (2021). Запозичення в термінології нанотехнологій. Лінгвістичні дослідження, 55, 68-75. DOI: https://doi.org/10.34142/23127546.2021.55.07 